\section{Adverse reactions to oxacillin in hospitalized children: a prospective study}

\section{Reações adversas à oxacilina em crianças hospitalizadas: um estudo prospectivo}

Mariana de Oliveira Brizeno de Souza 1 Maria da Conceição Castro de Araújo 2 Raquel Araújo de Santiago 3 Helena Lutéscia Luna Coelho 4 Marta Maria de França Fonteles 5

1-5 Faculdade de Farmácia, Odontologia e Enfermagem. Universidade Federal do Ceará. Rua Delmiro de Farias, 1799. Fortaleza, CE, Brasil. CEP: 60.430-170. E-mail: marianabrizeno@bol.com.br

\begin{abstract}
Objectives: follow-up of children exposed to oxacillin during hospitalization focusing on adverse reactions.

Methods: patients were selected from the pediatric wards of two hospitals in Fortaleza (Hospital Universitário Walter Cantídio-HUWC and Hospital Infantil Albert Sabin-HIAS) from the first oxacillin prescription with a prospective cohort study between October, 2000 and July, 2001 (HUWC) and July/2001 and March, 2002 (HIAS). Patients' follow-up was performed by daily visits to the wards and medical charts and prescription analysis. Suspected oxacillininduced adverse reactions (OxAR cases) were notified and classified according to causality and severity. Related statistic tests were completed.

Results: of the 130 patients exposed to oxacillin, 27 had OxAR (20.8\%). Fever was the most frequent reaction (50\%) followed by rash (35.7\%). The majority of reactions were considered Probable, for oxacillin was the only medication involved and $92.6 \%$ of the cases had Moderate severity with the need of therapeutic interventions caused by OxAR. A significant relation between oxacillin exposure time and OxAR was determined as well as hospitalization time and the appearance of adverse reactions. Exposure time over 14 days to oxacillin was established as a risk factor for OxAR (relative risk $=5.49$ ).

Conclusions: careful administration of oxacillin in children is recommended with established treatment duration. Empiric and prolonged use must be avoided.
\end{abstract}

Key words Oxacillin, Monitoring, Adverse reaction, Pharmacotherapeutic follow-up

\section{Resumo}

Objetivos: acompanhar crianças expostas à oxacilina durante hospitalização, com foco na incidência de reações adversas.

Métodos: os pacientes foram selecionados em enfermarias pediátricas de dois hospitais de Fortaleza (Hospital Universitário Walter Cantídio-HUWC e Hospital Infantil Albert Sabin-HIAS), desde a primeira prescrição de oxacilina, sendo feita coorte prospectiva entre outubro, 2000 e julho, 2001 (HUWC), e entre julho,2001 e março,2002 (HIAS). O seguimento de pacientes deu-se através de visitas diárias às enfermarias e análise de prontuários e prescrições. Os casos de RAOx foram notificados e classificados quanto à causalidade e gravidade, sendo realizados testes estatísticos pertinentes.

Resultados: dos 130 pacientes expostos à oxacilina, 27 apresentaram RAOx (20,8\%), sendo febre a reação mais freqüente (50\%), seguida do rash cutâneo $(35,7 \%)$. A maioria das reações foi considerada Provável, pois a oxacilina foi o único medicamento envolvido e 92,6\% dos casos tiveram gravidade Moderada, sendo necessárias intervenções terapêuticas devido à RAOX. Uma associação significante entre tempo de exposição à oxacilina e aparecimento de RAOx, assim como entre tempo de internamento e ocorrência de reação foi observada. Um tempo de exposição maior que 14 dias apresentou-se como fator de risco para ocorrência de RAOx (risco relativo $=5,49)$.

Conclusões: recomenda-se administração cautelosa de oxacilina em crianças, com duração do tratamento estabelecida, evitando-se tratamento empírico e uso prolongado.

Palavras-chave Oxacilina, Monitorização, Reação adversa, Seguimento farmacoterapêutico 


\section{Introduction}

Because pediatric patients are not included in clinical essays for medication therapeutic activity and safety assessment, they are the class of users most exposed to undesirable side effects. ${ }^{1,2}$ In addition the pharmacokinetic and pharmacodynamic features of this age group change with time and the result is that children are particularly vulnerable to inadequate medication use.

Infections are the most common cause of childhood disease and that explains the high prevalence of antimicrobial prescription in pediatrics.3-8 Oxacillin is a $\beta$-lactamase methicylin-resistant drug belonging to the isoxazolylpenicillins class used for Staphylococcus infections such as furunculosis, bronchopneumonia, abscesses, osteomelitis, meningitis, septicemias, septic arthritis, endocarditis, scalded skin syndrome and other conditions caused by other penicillin resistant Staphylococcus. 9,10

This medication may cause hypersensitivity reactions in patients allergic to penicillin or with asthma. Immediate reactions generally occur within 20 minutes following intake and may cause urticaria, angioneurotic edema, laryngospasm, vascular collapse and death. These anaphylactic reactions are very rare and generally occur following parenteral administration, but there are cases occurring after oral treatment. Retarded allergic reactions may be noted in general after two to four weeks of therapy following antimicrobial treatment involving conditions like the serum sickness. ${ }^{11}$ Dahlgren et al.12 determined a high number of oxacillin and nafcillin adverse reactions in comparison with other antiinfectious drugs when reviewing patients records who received antimicrobial therapy between 1990 and 1994 connecting their findings to the rates of medication adverse reactions documented in these patients.

The most frequent reactions were rash and phlebitis. A study performed in patients with ages varying from two to nine years old and investigating laboratorial exams like erythrocyte sedimentation rates, reactive protein $\mathrm{C}$ and liver function tests in patients developing these symptoms also demonstrated the occurrence of more frequent adverse reactions to medication in patients treated with oxacillin as compared to other antimicrobial agents, with many cases of hepatotoxicity and rash. ${ }^{13}$ Reports to a type of oxacillin related hepatitis 14 and neutropenia with isoxazolylpenicillins 15,16 have been made. Souza et al. 17 demonstrated that exposure to oxacillin is a risk factor for potentially severe adverse reactions, as for example in the case of inter- stitial nephritis; therefore its use is counter-indicated in nephropathies.

In the Brazilian pharmaceutical market, oxacillin is the only isoxazolylpenicillins in the National List of Essential Medications, 18 exclusively for hospital use. It is sold in ampoule bottles and capsules, with a high degree of endovenous use in hospital environments. The medication is sold by eight pharmaceutical laboratories in the generic and similar forms.

Adverse reactions to oxacillin represent $14.4 \%$ of the cases of medical adverse reactions registered by the Pharmacosurveillance Center of Ceará (Ceface) in the year of 1999 and there is a growing number of cases of adverse reactions to oxacillin (OxAR) in relation to the total number of notifications (1.6, 13.1 and $14.4 \%$ in 1997,1998 and 1999 respectively). Reactions were more frequent in males principally in the 1 to 14 year old group. In the year of 1999 a severe and a fatal case of medical adverse reaction to this antimicrobial agent occurred, both involving children. The fatal case resulted from an anaphylactic reaction during oxacillin infusion in a one year old child. The increase of these reactions called the attention of healthcare professionals in the hospitals assisted by Ceface, particularly in pediatrics, who demonstrated their concern to the pharmacosurveillance service.

Faced with the problem, this paper has the objective of investigating and describing adverse reactions to oxacillin in children in the two main hospitals of the city of Fortaleza, Ceará, the first being a general hospital (Hospital Universitário Walter Cantídio (HUWC) H1) and the second a pediatric hospital (Hospital Infantil Albert Sabin (HIA)S; H2).

\section{Methods}

A cohort prospective study in children exposed to oxacillin in the pediatric wards of two public hospitals of Fortaleza was performed. In H1, 42 patients were followed-up in the period from October 2000 to July 2001 and in $\mathrm{H} 2,88$ patients were monitored from July 2001 to March 2002. The children receiving their first oxacillin prescription while hospitalized were introduced in the study following the informed consent of their parents and guardians, all rights of remaining anonymous respected according to the reports of the ethical committees of both institutions, and following the authorization of both patients, daily confirmed until hospital discharge or patients' death.

The following data sources were utilized: direct interviews with the patient's guardian, interviews 
with the hospital staff, medical files (medical and nursing reports), prescriptions (first and second copies enclosed in the medical file and in the hospital pharmacy, respectively) and laboratorial exams added to the medical files.

Prescribed medication was closely monitored to determine the prescription-administration relation, investigating the causes for prescription changes and possible link with the use of oxacillin. Other information collected from the medical files were: social and demographic data, clinical history, laboratorial exams results, dose and exposure time to oxacillin, adverse reaction, day of treatment in which the adverse reaction occurred, oxacillin replacement for other antimicrobial agent and medication use to treat reaction.

In the case of oxacillin adverse reactions registration in the standard form of notification and referral to Ceface was entered for purposes of evaluation and classification of adverse reactions. OxAR suspicions were assessed for causality and severity through the Pharmacosurveillance Program of the World Health Organization (WHO) 19 standardized by Ceface20,21 and inserted into a database (Epi Info, version 6.2).

Reactions and all medication involved were codified according to the World Health Organization - Adverse Reaction Terminology (WHO-ART) and the classification of Anatomical Therapeutic Chemical (ATC) respectively. Means for central tendency and variables variability, such as average and standard deviation were calculated and hypothesis tests performed, with OxAR occurrence or non-occurrence established as the dependent variable. The calculation of the relative risk for OxAR was made through the contingency table when exposure exceeded 14 days compared with the duration of the treatment for a period equal or less than 14 days. For statistical analysis purposes variance tests analysis (ANOVA), Kruskal Wallis and the ChiSquare Test with $p<0.05$ and confidence interval (CI) at $95 \%$ were utilized.

\section{Results}

Considering the total number of children exposed to oxacillin, a higher incidence of exposure of males (74 children, $56.9 \%$ ) was observed. The age mean was 3.5 , varying from 0 to 16 years old. Hospitalization and exposure time corresponded to $25.8 \pm 23.3$ days and $14.4 \pm 6.0$ days respectively. The mean dose of oxacillin used was 216.3 (DP = 121.4) mg/kg/day. (Table 1)
Table 1

Description of population under study $(\mathrm{N}=130)$.

\begin{tabular}{ll}
\hline Variables & $\bar{X} \pm$ SD (min-max) \\
\hline Age (years) & $3,5 \pm 4,2(0-16)$ \\
Weight (kg) & $14,1 \pm 10,1(2,7-55)$ \\
Daily Dose (g) of Oxacillin & $2,8 \pm 2,1(0,2-15)$ \\
Dose/kg/day (mg) of Oxacillin & $216,3 \pm 121,4(21-828)$ \\
Hospitalization (days) & $25,8 \pm 23,3(5-210)$ \\
Exposure Time (days) & $14,4 \pm 6,0(1-37)$ \\
\hline
\end{tabular}

Of the 130 patients exposed to oxacillin, $27 \mathrm{had}$ adverse reaction (accumulated incidence of 20.8\%) with a total of 3.352 patients/day followed up and incidence density of $0.8 \%$. As we can observe in Table 2, the principal manifestation of OxAR noted was rash, occurring in a given time length and preceded in many cases of fever peaks. The more frequent adverse reaction was fever $(50 \%)$ generally occurring between the $11^{\text {th }}$ and $16^{\text {th }}$ day of treatment $(85.6 \%)$ followed by rash $(35.7 \%)$ principally after the $16^{\text {th }}$ day of treatment $(86.6 \%)$. Other adverse reactions noted were: urticaria, leucopenia, facial edema and itching, a total of 43 reactions reported. Management more utilized in the event of OxAR was to stop oxacillin (51.9\%). In some cases (48.1\%) oxacillin treatment was continued with the simultaneous administration of antihistaminics and/or corticoids. In the cases where oxacillin was stopped, treatment was replaced specially by vancomycin $(40 \%)$ and by cephalexin (33.3\%). As for OxAR, treatment dipyrone, different antihistaminics and hydrocortisone were used for $44.4,33.3$ and $22.2 \%$ of patients with reaction, respectively.

OxAR cases were assessed according to causality and severity (Table 3 ). In $55.6 \%$ of the cases, oxacillin was the only medication suspected of causing the reaction and in $7.4 \%$ reaction took place during or right after the infusion with oxacillin (probable and defined causality respectively). In the majority of cases (92.6\%) OxAR was considered moderate when medication to treat the symptoms of reaction and/or oxacillin use was stopped.

Table 4 depicts variables comparison (weight, dose, age, exposure time to oxacillin, hospitalization and dose $/ \mathrm{kg} /$ day) between groups of patients using oxacillin with OxAR (+) reaction or OxAR (-) no reaction. It was determined that the mean exposure time to oxacillin was of 19.4 days in patients with OxAR and of only 13.1 in the patients with no adverse reactions. Hospitalization time mean was 
Table 2

Description of adverse reactions to oxacillin and medical procedure.

\begin{tabular}{|c|c|c|c|c|c|c|c|c|}
\hline $\begin{array}{l}\text { Reaction } \\
\text { (WHO - ART) }\end{array}$ & $\mathbf{n}$ & $\%$ & $\begin{array}{c}\text { Oxacillin } \\
\text { Substitutes * } \\
\text { (ATC) }\end{array}$ & $\mathbf{n}$ & $\%$ & $\begin{array}{l}\text { Medication used } \\
\text { due to OxAR ** } \\
\text { (ATC) }\end{array}$ & $\mathbf{n}$ & $\%$ \\
\hline $\begin{array}{l}\text { Fever } \\
(18100725)\end{array}$ & 21 & 50,0 & $\begin{array}{l}\text { Imipenem } \\
\text { (J01DH51) }\end{array}$ & 1 & 6,7 & $\begin{array}{l}\text { Dipyrone } \\
\text { (N02BB02) }\end{array}$ & 12 & 44,4 \\
\hline $\begin{array}{l}\text { Rash } \\
(01000028)\end{array}$ & 15 & 35,7 & $\begin{array}{l}\text { Cephalexin } \\
\text { (J01DA01) }\end{array}$ & 5 & 33,3 & $\begin{array}{c}\text { Hydrocortisone } \\
\text { (H02AB09) }\end{array}$ & 6 & 22,2 \\
\hline $\begin{array}{l}\text { Urticaria } \\
(01000044)\end{array}$ & 3 & 7,1 & $\begin{array}{l}\text { Vancomycin } \\
\text { (J01XA01) }\end{array}$ & 6 & 40,0 & $\begin{array}{l}\text { Hydroxizine } \\
\text { (N05BB01) }\end{array}$ & 3 & 11,1 \\
\hline $\begin{array}{l}\text { Leucopenia } \\
(12200908)\end{array}$ & 2 & 4,8 & Other & 3 & 20,0 & Clemastine & 3 & 11,1 \\
\hline $\begin{array}{l}\text { Facial Edema } \\
(18100602)\end{array}$ & 1 & 2,4 & - & - & - & Dexchlorpheniramine & 3 & 11,1 \\
\hline $\begin{array}{l}\text { Itching } \\
(01000024)\end{array}$ & 1 & 2,4 & - & - & - & Other & 14 & 51,8 \\
\hline Total & 43 & 100,0 & & 15 & 55,5 & & 41 & 151,7 \\
\hline
\end{tabular}

* In 15 cases OxAR was replaced by other medication; * Approximately 27 patients had OxAR and of these 26 received at least one medication to treat reaction. Note: In parenthesis: the classification of adverse reaction according to WHO-ART (World Health Organization - Adverse Reaction Terminology) and medication (Anatomical Therapeutic Chemical - ATC).

Table 3

OXAR classification related to cause and severity.

\begin{tabular}{lrrrrr}
\hline Cause & $\mathbf{n}$ & $\%$ & Severity & $\mathbf{n}$ & $\%$ \\
\hline Defined & 2 & 7,4 & Moderate & 25 & 92,6 \\
Probable & 15 & 55,6 & Mild & 02 & 7,4 \\
Possible & 10 & 37,0 & & & \\
Total & 27 & 100,0 & & 27 & 100,0
\end{tabular}

Note: Cases suspicious of OxAR were classified according to the World Health Organization for causality and severity in percentage form.

Table 4

Mean values of the variables studied in patients utilizing oxacillin with and without adverse reactions.

\begin{tabular}{lrrr}
\hline Variable & OxAR(-) & OxAR(+) & p-value \\
\hline Weight (kg) & 13,8 & 15,4 & 0,455 \\
Age (years) & 3,4 & 4,1 & 0,456 \\
Exposure time (days) & 13,1 & 19,4 & $<0,001$ \\
Hospitalization time (days) & 23,9 & 33,0 & $<0,001$ \\
Dose (mg/kg/day) & 221,8 & 195,9 & 0,709 \\
\hline
\end{tabular}

Comparisons: weight, age and exposure time (ANOVA); dose and hospitalization time (Kruskal-Wallis Test).

\section{Table 5}

Frequency distribuition of the patients according to sex and exposure time to oxacilin.

\begin{tabular}{|c|c|c|c|}
\hline Variable & $\begin{array}{r}\text { OxAR (-) } \\
n(\%)\end{array}$ & $\begin{array}{r}\text { OxAR (+) } \\
n(\%)\end{array}$ & $p$-value \\
\hline \multicolumn{4}{|l|}{ Sex } \\
\hline Female & $43(76,8)$ & $13(23,2)$ & 0,550 \\
\hline Male & $60(81,1)$ & $14(18,9)$ & \\
\hline \multicolumn{4}{|c|}{ Exposure Time } \\
\hline$\leq 14$ days & 93,1 & 6,9 & $<0,001$ \\
\hline$>14$ days & 62,1 & 37,9 & \\
\hline
\end{tabular}

Comparisons: Chi-Square Test

33.5 in the group of patients with OxAR and 24 days in the patients with no adverse reactions. The differences between the means of the two variables were statistically significant $(p=0,05 ; 95 \% \mathrm{CI})$. Relative risk (RR) of oxacillin exposure for more than 14 days was of $5.49(37,9 / 6,9)$ for OxAR. (Table 5) 


\section{Discussion}

This paper, although prospective did not include the reasons for oxacillin prescription nor investigation related to the treatment, whether empiric or not. The fact that these hospitals were university hospitals value the findings because of the presumption of their involvement in priority issues related to the rational use of medication, with standardization and control, as well as continuous professional training. In addition to this, the population studied is characteristic of the major pediatrics patients of the northeastern region in terms of social and demographic data, pharmacokinetic features and main health problems, for reference hospitals are the hospitals of choice of the community for emergency medical care.

Oxacillin adverse reaction incidence in the population studies was of $20.8 \%$, value which is much higher to the rates determined by Impicciatore et $a l ., 22$ in a metanalysis published in $2001(9.53 \%$, $95 \% \mathrm{CI} ; 6.81-12.26$ ). A density incidence equal to 0.8 was determined, a value equivalent to the one established by Santos, 23 in a study that monitores 265 pediatric patients in a public hospital of Fortaleza with an incidence of adverse reaction to medication of $12.5 \%$ in these patients.

Oxacillin adverse reaction is characterized by fever and rash. Literature reports that the majority of severe adverse effects related to oxacillin is due to the cross reaction noted in penicillin hypersensitive patients. Manifestations include, among others syndromes like the serum sickness (fever, urticaria, angioneurotic edema, itching) and a variety of skin rashes. 10,24,25 Differently from other drugs, dermatological reactions related to penicillin use can occur following one week of treatment. 26 The same authors report that, for example, the increase frequency of contact eczema caused by cloxacillin an isoxazolylpenicillins, can also stem from its typical irritating and lipophilic properties.

Our study determined a prolonged use of oxacillin (an everage of 14 days). The higher incidence of reactions in the exposed group for over 14 days points towards a hypersensitivity, maybe retarded, with the occurrence mechanism. Nevertheless, the daily median dose of oxacillin used equaled $216,3 \mathrm{mg} / \mathrm{kg}$ of weight, higher than the recommended dose (100 to $200 \mathrm{mg} / \mathrm{kg}$ of weight $)^{27}$ therefore, a dose-dependent possibility may not be discarded. A detailed investigation on the probable mechanism of adverse reactions has not been made in this paper.

In the studies of adverse reactions monitoring, classification related to causality and severity enables the adequate linking of the causing agent to the adverse reactions encouraging the idea of aggravations stemming from reaction. Our results particularly demonstrated that the majority of the reactions were considered probable, for oxacillin was the only medication involved in the reaction, and there were two causes classified as defined, that is, reaction occurred during medication infusion. Some of the cases were considered as being of possible causality, for other medication, in addition to oxacillin were considered suspect of causing the reaction. Nevertheless, no case of oxacillin was discarded as possible agent to adverse medication reaction.

As for adverse reactions, the cases, in their majority were considered as being moderate for therapeutic interventions caused by OxAR, as for example, change of antimicrobial medication and/or use of medications to treat the reaction. In many of these cases, the use of dipyrone and antihistaminics was made. It should be emphasized that corticoid and antihistaminics administration worked in the majority of the cases as an adverse reaction indicator.

As for replacement with other antibiotics, the use of cephalosporines or clindamycin, depending on hospital's policy, has been suggested by Van den Boom et al.16 In our study, oxacillin was replaced principally by vancomycin and cephalexin. An efficacy and safety assessment of antimicrobial therapy performed by Wynn et al.28 has shown that vancomycin was associated wih a significant number of side effects more than oxacillin and cephalosporin's such as cephtriaxone and cephazolin.

An statistically significant association between exposure time to oxacillin and the appearance of OxAR was noted in our findings. The longer the exposure the more frequent adverse reactions of oxacillin in pediatrics. Exposure time over 14 days revealed a risk factor for the occurrence of OxAR compared to a period shorter or equal to 14 days. Roughhead et al. ${ }^{29}$ while studying a series of risks for reactions occurrence related to flucloxacillin, an oxacillin analogue, also identified as a risk factor for adverse reactions, treatment duration beyond 14 days. Precaution information related to exposure time to this antimicrobial drug is reported in the medication instructions. Similarly, Van den Boom et al. 16 describing cases of children with neutropenia diagnosis related to flucloxacillin also reported the need to monitor patients receiving this antimicrobial agent for over two weeks. 13,16

Another significant association was found in our study: between hospitalization time medians of the 
groups of patients with and without OxAR. This was important to determine the increase of hospitalization time caused by adverse reactions. 30

The problem of adverse reactions to isoxazolylpenicillins in some countries has encouraged studies on the possible therapeutic alternatives to these antibiotics to be used specially in cases where risk factors are present. Linezolide compared by Gener et al. 31 with oxacillin and dicloxacillin in patients with complicated infections in the skin and soft tissues was better tolerated and safe with the additional advantages of convenient dosage. None of the patients had severe adverse reaction or higher incidence of adverse reactions when compared to oxacillin. The most frequent adverse effects of linezolide reported were: nausea, cephalea, vomiting, hypertension, diarrhea and injection local pain, plus some alterations on tongue color and taste, elevation of hepatic enzymes and thrombocytopenia. In Brazil, registration was awarded by the National Agency of Sanitary Surveillance (Agência Nacional de Vigilância Sanitária - ANVISA), in June, 2000, with particular need of further safety studies for children.

Cephalexin was also reported as a possible alternative therapy in the treatment of soft tissues infection 29 nevertheless there are no studies comparing its efficacy with oxacillin or analogues. Palacios et al.32 assessed the efficacy of cephuroxime compared to a combination of dicloxacillin and chloraphenicol in the treatment of children with parapneumonic effusion or empyema. Study results suggested that cephuroxime its an effective and well tolerated alternative for children with such diagnosis treatment.

Gonzáles et al.30 declared that in general, adverse reactions increase healthcare costs for they produce new diseases delaying base disease cure. Although a pharmaceutical and economic study has

\section{References}

1. Shirkey H. Therapeutic orphans. Pediatrics. 1999; 104: 583-4

2. Bonati M, Impicciatore P, Pandolfini C. Registering clinica trials. Register of clinical trials in children must be set up. BMJ. 2000; 320: 1339-40.

3. Loda FA, Glezen WP, Clyde Jr. WA. Respiratory disease in group day care. Pediatrics. 1972; 49: 428-37.

4. Loe E, Lott J, McDowell J, Munari G, O' Callaghan C. Paediatric pharmacopeia. London: Saunders; 1998.

5. Chang MR, Carvalho NCP, Oliveira ALL, Moncada PMF, Moraes BA, Asensi MD. Surveillance of pediatric infections in a teaching hospital in Mato Grosso do Sul, Brazil. Braz J Infect Dis. 2003; 7: 149-60. not been performed, adverse reactions caused by the use of oxacillin certainly increase hospitalization costs, including adverse reactions treatment costs, and, the replacement of the causing agent for more expensive antibiotics. In addition, oxacillin is replaced by antimicrobial drugs of therapeutic reserve, such is the case of vancomycin therefore causing bacterial resistance risk increase.

In this context, our results are consistent with the results of Van den Boom et al. ${ }^{16}$ suggesting the need for isoxazolylpenicillins, such as flucoxacillin in relation to doses and clinical monitoring in general, including hepatic function tests, weekly neutrophile count in patients receiving this antimicrobial agent for more than two weeks. Our finding point towards the need of careful oxacillin administration to children. Hospital Infection Control Committee should be careful avoiding empiric and prolonged use of this medication, considering that relationship between oxacillin exposure time and adverse reactions appearance was established. These measures are important and necessary to assure the rational use of oxacillin and base the Committee of Pharmacy and Therapy in the periodical assessment of standardization list of hospital medications.

\section{Acknowledgements}

To the National Council for Scientific and Technological Development - Conselho Nacional de Desenvolvimento Científico e Tecnológico (CNPq) and the Fundação Cearense de Apoio a Pesquisa (FUNCAP) Foundation for Research Support of Ceará, through the award of scientific initiation and master's programs scholarships respectively.

6. American Academy of Pediatrics. Active and passive immunization. In: Pickering LK, editor. Red book: report of the Committee on Infectious Diseases. 26. ed. Elk Grove Village, 2003. p. 1-98.

7. Cunha AJ, Santos SR, Martines J. Integrated care of childhood disease in Brazil: mothers' response to the recommendations of health workers. Acta Paediatr. 2005; 94: 1116-21.

8. Brady MT. Infectious disease in pediatric out-of-home child care. Am J Infect Control. 2005; 33: 276-85.

9. Charles FL, Lora LA, Morton PG, Leonard LL. Drug information handbook. Hudson: Apha; 2000.

10. Ellswarth AJ, Witt DA, Dugdale DC, Oliver M. Medical drug reference. St. Louis: Mosby, 2002. 
11. Tierney Jr LM, McPhee SJ, Papadakis MA. Current Medical diagnosis \& treatment. Columbus, OH: McGrawHill; 2003.

12. Dahlgren AF. Adverse drug reactions in home care patients receiving nafcillin or oxacillin. Am J Health Syst Pharm. 1997; 54: 1176-9.

13. Maraqa NE, Gomez MM, Rathore MH, Alvarez AM. Higher occurrence of hepatotoxicity and rash in patients treated with oxacillin, compared with those treated with nafcillin and other commonly used antimicrobials. Clin Infect Dis. 2002; 34: 50-4.

14. Onorato IM, Axelrod AL. Hepatitis from intravenous highdose oxacillin therapy. Ann Intern Med. 1978; 89: 497-500.

15. Rello J, Gatell JM, Miro JM, Martinez JA, Soriano E, Garcia San Miguel J. Secondary effects associated with cloxacillin. Med Clin. (Barc) 1987; 89: 631-3.

16. Van den Boom J, Kristiansen JB, Voss LM, Stott NS. Flucloxacillin associated neutropenia in children treated for bone and joint infections. J Paediatr Child Health. 2005; 41: 48-51.

17. Souza RL, Lacerda RM, Almeida GC, Silva IB. Nefrite intersticial induzida por drogas. CCS 1993; 12: 56-7.

18. Ministério da Saúde. Relação Nacional de Medicamentos Essenciais: RENAME - 2000. Brasília, DF; 2000.

19. Uppsala Monitoring Centre World Health Organization. Guidelines for setting up and running a Pharmacovigilance Centre. Uppsala; 2000.

20. Coelho HL. Farmacovigilância: um instrumento necessário. Cad Saúde Pública. 1998; 14: 871-5.

21. Coelho HL, Arrais PSD, Gomes AP. Sistema de farmacovigilância do Ceará: um ano de experiência. Cad Saúde Pública. 1999. 15: 631-40.

22. Impicciatore P, Choonara I, Clarkson A, Provasi D, Pandolfini $\mathrm{C}$, Bonati $\mathrm{M}$. Incidence of adverse drug reactions in paediatric in/out-patients: a systematic review and meta-analysis of prospective studies. Br J Clin Pharmacol. 2001; 52: 77-83.
23. Santos DB. Perfil de utilização de medicamentos e monitorização de reações adversas em pacientes pediátricos no Hospital Infantil Albert Sabin [dissertação mestrado]. Fortaleza: Faculdade de Farmácia, Odontologia e Enfermagem da Universidade Federal do Ceará; 2002.

24. Katzung BG. Basic \& clinical pharmacology. Columbus: McGraw Hill; 2001.

25. DiPiro JT. Pharmacists drug handbook. Bethesda: ASHP; 2001.

26. Bigby M, Jick S, Jick H, Arndt K. Drug-induced cutaneous reactions. A report from the Boston Collaborative Drug Surveillance Program on 15,438 consecutive inpatients, 1975 to 1982. JAMA. 1986; 256: 3358-62.

27. Korolkovas A. Dicionário terapêutico. São Paulo: Guanabara Koogan; 1998.

28. Wynn M, Dalovisio JR, Tice AD, Jiang X. Evaluation of efficacy and safety of outpatient parenteral antimicrobial therapy for infections with methicillin-sensitive Staphylococcus aureus. South Med J. 2005; 98: 590-5.

29. Roughead EE, Gilbert AL, Primrose JG. Improving drug use: a case study of events which led to changes in use of flucloxacillin in Austrália. Soc Sci Med. 1999; 48: 845-53.

30. González MG, Díaz MSM, Martinez AM, Ortiz M. Heparin-induced hypercalemias: a prospective study. Int J Clin Pharmacol Ther Toxicol. 1998; 29: 1194-9.

31. Gener AG, Salvador P. Linezolida: una nueva alternativa en infecciones por gram positivos. Farm Hosp. 2002; 26: 44-8.

32. Palacios GC, González SN, Perez FL, Cuevas SF, Solórzano SF. Cefuroxime vs a dicloxacillin/chloramphenicol combination for the treatment of parapneumonic pleural effusion and empyema in children. Pulm Pharmacol Ther. 2002; 15: 17-23. 